GRASAS Y ACEITES 65 (1)

January-March 2014, e001

ISSN-L: 0017-3495

doi: http://dx.doi.org/10.3989/gya.035713

\title{
Olive oils from Algeria: Phenolic compounds, antioxidant and antibacterial activities
}

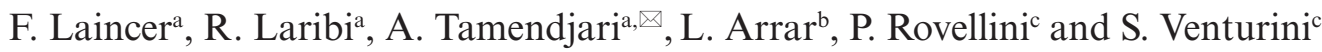 \\ a Laboratory of Applied Biochemistry, Faculty of Natural and Life Sciences, University of Bejaia, Algeria \\ 'Laboratoire de Biochimie Appliquée, Département de Biologie, Université Ferhat Abbas, Sétif, Algeria \\ 'INNOVHUB - Stazioni Sperimentali per l' Industria-Via Giuseppe Colombo N. 79- Milan- Italy \\ Corresponding author: abderezakt@yahoo.fr
}

Submitted: 4 March 2013; Accepted: 9 September 2013; Published on line: 13/02/2014

SUMMARY: The phenolic compositions, antioxidant and antimicrobial activities against six bacteria of phenolic extracts of olive oil varieties from eleven Algerian varieties were investigated. The antioxidant activity was assessed by determining the scavenging effect on the DPPH and ABTS ${ }^{+}$radicals. The antimicrobial activity was measured as a zone of inhibition and minimum inhibitory concentration (MIC) on human harmful and foodborne pathogens. The results show that total phenols was significantly $(p<0.05)$ correlated with DPPH $(\mathrm{r}=0.72)$ and $\mathrm{ABTS}^{+}$radicals $(\mathrm{r}=0.76)$. Among the bacteria tested, $S$. aureus and to a lesser extent $B$. subtilis showed the highest sensitivity; the MIC varied from 0.6 to $1.6 \mathrm{mg} \cdot \mathrm{mL}^{-1}$ and 1.2 to $1.8 \mathrm{mg} \cdot \mathrm{mL}^{-1}$, respectively. The results reveal that Algerian olive oils may constitute a good source of antioxidant and antimicrobial agents.

KEYWORDS: Antibacterial activity; Antioxidant activity; Olive oil; Phenols

RESUMEN: Aceites de oliva de Argelia: Componentes fenólicos, actividades antioxidante y antibacteriana. Se ha estudiado la composición fenólica y las actividades antioxidante y antimicrobiana, contra seis bacterias, de extractos de aceites de oliva de once variedades argelinas. La actividad antioxidante se evaluó mediante la determinación del efecto captador de radicales de DPPH y ABTS ${ }^{+}$. La actividad antimicrobiana se midió como zona de inhibición y como concentración inhibitoria mínima (MIC) sobre bacterias perjudiciales humanas y agentes patógenos transmitidos por los alimentos. Los resultados mostraron que los fenoles totales está significativamente $(\mathrm{p}<0,05)$ correlacionados con DPPH $(\mathrm{r}=0,72)$ y los radicales ABTS $+(\mathrm{r}=0,76)$. Entre las bacterias ensayadas, $S$. aureus y, en menor grado B. subtilis mostraron la mayor sensibilidad; el MIC varió de 0,6 a 1,6 $\mathrm{mg} \cdot \mathrm{mL}^{-1}$ y 1,2 a $1,8 \mathrm{mg} \cdot \mathrm{mL}^{-1}$ respectivamente. Los resultados muestran que los aceites de oliva argelinos pueden constituir una buena fuente de antioxidantes y agentes antimicrobianos.

PALABRAS CLAVE: Aceite de oliva; Actividad antibacteriana; Actividad antioxidante; Fenoles

Citation/Cómo citar este artículo: Laincer F, Laribi R, Tamendjari A, Arrar L, Rovellini P, Venturini S. 2014. Olive oils from Algeria: Phenolic compounds, antioxidant and antibacterial activities. Grasas Aceites 65 (1): e001. doi: http:// dx.doi.org/10.3989/gya.035713.

Copyright: (C) 2014 CSIC. This is an open-access article distributed under the terms of the Creative Commons Attribution-Non Commercial (by-nc) Spain 3.0 Licence. 


\section{INTRODUCTION}

The Mediterranean diet is associated with lower incidences of atherosclerosis, cardiovascular disease, neurodegenerative diseases and certain types of cancer. The apparent health benefits have been partially ascribed to the dietary consumption of virgin olive oil by Mediterranean populations (Cicercale et al., 2010). The beneficial effects of virgin olive oil were attributed to its high monounsaturated fatty acids particularly oleic acid and minor compounds such as phenolic compounds, tocopherols and carotenoids (Visioli and Galli, 1998).

Recently, phenolic compounds present in olive oil have received much attention due to their beneficial functional and nutritional effects including antioxidant and antimicrobial activities. In addition to extending the shelf life of foods by inhibiting lipid peroxydation, phenolic compounds scavenge free radicals and can consequently protect the human body (Cicerale et al., 2009). Numerous studies have demonstrated the antioxidant activity of olive oil polyphenols (Visioli et al., 2002, Servili et al., 2009).

Moreover, several studies have shown that the phenolic compounds in olive oil have a high antimicrobial activity against a broad spectrum of foodborne pathogens (Medina et al., 2006; Karaosmanoglu et al., 2010). Oleuropein (Bisignano et al., 1999; Furneri et al., 2004), hydroxytyrosol (Bisignano et al., 1999) which inhibits or delays the growth rate of a range of bacteria. Romero et al. (2007) reported that the dialdehydic form of decarboxymethyl oleuropein aglycon and the dialdehydic form of decarboxymethyl ligstroside aids in inhibiting the growth of Helicobacter pylori. Recently, Bubonja-Songe et al. (2011) indicated that olive oil polyphenols can be used as an alternative for the prevention of food spoilage and monocytogenes contaminated with Listeria. The increasing resistance to antibiotics represents the main factor justifying the need to find out and/or develop new antimicrobial agents. Although strategies have been proposed in an attempt to control the pathogenic bacteria spread, the search for new methods to treat infections stimulates the investigation for natural compounds.

Algeria, one of the main producers of olive oil in the world (9th), has a wide range of varieties. Several studies on Algerian olive oil characterization have been carried out. However, there is no report about antioxidant and antimicrobial activities of phenolic compounds in the olive oil produced in Algeria. The present work was undertaken (i) to identify and quantify the phenolic compounds from various olive oils from Algerian varieties using a reverse-phase high-performance liquid chromatography (RP-HPLC) system and (ii) to evaluate the antioxidant and antimicrobial properties of olive oils obtained from different varieties of olives grown in the Bejaia region (Algeria).

\section{MATERIALS AND METHODS}

\subsection{Fruit harvest}

The extra virgin olive oils used in this work came from eleven different Algerian varieties of olives: Aghenfas, Akerma, Blanquette de Guelma, Bouchouk Soummam, Bouricha, Chemlal, Ferkani, Limli, Neb Djemel, Tabelout and Chemlal Tazmalt.

Fruits were manually harvested from an orchard located in Takerietz (Bejaia), during the 2008 and 2009 seasons, with the exception of the Chemlal Tazmalt variety which was harvested in the Tazmalt region (Bejaia) in east-central Algeria. Collection, transportation and processing of the olive samples were carried out rapidly and with care. Therefore, only fresh drupes without damage were selected.

\subsection{Olive oil extraction}

Virgin olive oil samples were obtained using a laboratory oil mill (Levi-Deleo-Lerogsame), consisting of three basic elements: a hammer crusher, thermo-beater (mixer) and a pulp centrifuge. The olive fruits were milled in the hammer crusher, and then the olive paste was kneaded for 30 min with the addition of warm water $(50 \mathrm{~mL}$ of water was added to $920 \mathrm{~g}$ of paste). After the vertical centrifugation, the oil was collected and left to stand. The oil samples were stored in amber glass bottles at $4{ }^{\circ} \mathrm{C}$ in the dark without headspace until analysis.

\subsection{Quality indices}

Acidity and peroxide values were determined following the analytical methods described by the International Union of Pure and Applied Chemistry (IUPAC, 1979). $\mathrm{K}_{232}$ and $\mathrm{K}_{270}$ were determined according to the analytical methods described by the International Olive Oil Council (IOOC, 1996).

\subsection{Liquid-liquid extraction of phenolic compounds}

A Liquid-liquid extraction system was carried out in the same extraction conditions, reported by Tsimidou et al. (1992) with some modifications. Briefly, $50 \mathrm{~g}$ of oil were dissolved in $50 \mathrm{~mL}$ of hexane, the solution was extracted successively three times with $30 \mathrm{~mL}$ of an $\mathrm{MeOH} /$ water (80:20, v/v) solution. The extracts were combined and washed twice with $50 \mathrm{~mL}$ of hexane to remove the residual oil. The hexane phase was discarded, and the methanolic solutions were concentrated and dried using rotary evaporator under vacuum at $40{ }^{\circ} \mathrm{C}$. Finally, the residue was re-dissolved in a solution of $\mathrm{MeOH} /$ water $(80: 20, \mathrm{v} / \mathrm{v})$. 


\subsection{Determination of total phenols}

The total phenolic content of the extract was determined by the Folin-Ciocalteu spectrophotometric method at $765 \mathrm{~nm}$, using gallic acid as calibration curve (Favati et al., 1994).

\subsection{Determination of $\boldsymbol{O}$-diphenols}

According to Bendini et al. (2003), $0.5 \mathrm{~mL}$ of phenolic extract obtained from olive oil were dissolved in $5 \mathrm{~mL}$ of $\mathrm{MeOH}$-water $(1: 1, \mathrm{v} / \mathrm{v})$; a mixture of $4 \mathrm{~mL}$ of the solution and $1 \mathrm{~mL}$ of a $5 \%$ solution of sodium molybdate dihydrate in $\mathrm{MeOH}$-water $(1: 1, \mathrm{v} / \mathrm{v})$ was shaken vigorously. After $15 \mathrm{~min}$, the absorbance at $370 \mathrm{~nm}$ was measured using caffeic acid for the calibration curve with a glass cuvette.

\subsection{Chromatographic determination of phenolic compounds}

A solution of internal standard $(1 \mathrm{~mL}$ of 0.015 $\mathrm{mg} \cdot \mathrm{mL}^{-1}$ of syringic acid in water/MeOH $(20: 80$ $\mathrm{v} / \mathrm{v})$ was added to a sample of virgin olive oil $(2 \mathrm{~g})$. The mixture was shaken $(30 \mathrm{~s})$ and $5 \mathrm{~mL}$ of extraction solution water and $\mathrm{MeOH}(20: 80 \mathrm{v} / \mathrm{v})$ were added. The obtained mixture was shaken for $1 \mathrm{~min}$, extracted for $15 \mathrm{~min}$ in an ultrasonic bath and then centrifuged at 5000 r.p.m. $(2500 \mathrm{~g})$ for $25 \mathrm{~min}$ at $\mathrm{T}=$ $20{ }^{\circ} \mathrm{C}$ (NGD., 2010). The upper phase was filtered with a $0.45 \mu \mathrm{m}$ PVDF syringe filter. $20 \mu \mathrm{L}$ of the filtered solution were analyzed by HPLC with a UV detector at $280 \mathrm{~nm}$. The HPLC system used consisted of a C18 Spherisorb ODS-2 reverse column $(5 \mu \mathrm{m}, 250 \mathrm{~mm}, 4.6 \mathrm{~mm})$. Elution was performed at a flow rate of $1 \mathrm{~mL} \cdot \mathrm{min}^{-1}$ following a gradient composed of a mixture of water and orthophosphoric acid (99.8:0.2 v/v) (solvent A), $\mathrm{MeOH}$ (solvent B) and acetonitrile (solvent C): from 96\% (A) - 2\% (B) $-2 \%(\mathrm{C})$ to $0 \%(\mathrm{~A})-50 \%(\mathrm{~B})-50 \%(\mathrm{C})$ in $60 \mathrm{~min}$. The last gradient was kept for $10 \mathrm{~min}$. The successive gradient was: from $0 \%(\mathrm{~A})-50 \%(\mathrm{~B})-50 \%(\mathrm{C})$ to $96 \%(\mathrm{~A})-2 \%(\mathrm{~B})-2 \%(\mathrm{C})$ in 2 min and then kept for $10 \mathrm{~min}$.

The identification of phenolic compounds was performed by HPLC-MS. The main phenolic compounds were identified by comparison with relative retention times and UV spectra of pure standards.

\subsection{Determination of antioxidant activity}

\subsubsection{DPPH radical- Scavenging assay}

The capacity of methanolic extracts of olive oil to reduce the DPPH (2,2-diphenyl-picrylhydrazyl) radical was assessed using the method of Keceli and Gordon (2001). $0.1 \mathrm{~mL}$ of a methanolic extract were added to $2.9 \mathrm{~mL}$ of a solution of DPPH $\left(6.10^{-5}\right.$ M) in methanol for $30 \mathrm{~min}$ and the absorbance was recorded at $515 \mathrm{~nm}$. The scavenging activity of the extracts was evaluated according to the formula:

$$
\text { percent of scavenging } \left.=\left[\mathrm{A}_{0}-\left(\mathrm{A}_{1}-\mathrm{A}_{\mathrm{S}}\right)\right] / \mathrm{A} 0\right] 100
$$

where $\mathrm{A}_{0}$ is the absorbance of DPPH alone, $\mathrm{A}_{1}$ is the absorbance of DPPH + extract and $A_{S}$ is the absorbance of the extract alone.

\subsubsection{Scavenging activity against the ABTS. ${ }^{+}$radical cation}

The total antioxidant activity of extracts was measured by the ABTS $^{+}$(2,2' -azinobis-(3-ethylbenzothiazoline-6-sulfonic acid) radical cation decolorization assay of Re et al. (1999) with minor modifications. $\mathrm{ABTS}^{+}$was generated by the oxidation of ABTS with potassium persulfate. Prior to assay, the ABTS ${ }^{+}$stock solution was diluted with ethanol to an absorbance of $0.700 \pm 0.020$ at $734 \mathrm{~nm}$. Then $990 \mu \mathrm{L}$ of a diluted ABTS ${ }^{+}$solution was mixed with $10 \mu \mathrm{L}$ of the test sample, and the absorbance was measured at $734 \mathrm{~nm}$ after $30 \mathrm{~min}$. The inhibition percentage of absorbance was calculated using the formula specified in the DPPH method. The antioxidant capacity of test compounds was expressed as $\mathrm{IC}_{50}$, the concentration necessary for $50 \%$ reduction of $\mathrm{ABTS}^{+}$

\subsection{Determination of antibacterial activity}

\subsubsection{Bacterial strains and culture conditions}

The bacterial strains used as test organisms were Escherichia coli Nalidixic Acid Resistant NAR, Klebsiella pneumoniae E47, Listeria innocua CLIP 74915, Pseudomonas aeruginosa; ATCC 27853, Staphylococcus aureus ATCC 25923 and Bacillus subtilis ATCC 6633. The bacteria were cultured at $37^{\circ} \mathrm{C}$ in a nutrient broth and agar medium. Before experimental use, the cultures from solid medium were sub-cultivated in a liquid medium, incubated for $18 \mathrm{~h}$ and used as the source of inoculums for each experiment.

\subsubsection{Antibacterial Activity Assay}

The agar diffusion method (Kappel et al., 2008) was used for the antibacterial assay. Suspensions of the microorganisms were prepared to contain approximately $10^{8} \mathrm{CFU} / \mathrm{mL}$ then $0.1 \mathrm{~mL}$ of the test organisms were inoculated with a sterile swab on the surface of the Mueller-Hinton agar. Sterile paper disks (6 $\mathrm{mm}$ in diameter) (REF-NO: 321 261, Antibiotica-testblattchen D 3354. Dassel W-Germany) were impregnated with $20 \mu \mathrm{L}$ of the extract solutions in order to obtain final concentrations of $1,0.5,0.25$ and $0.12 \mathrm{mg}$, respectively, of extract in the disks. Negative controls were prepared 
using the same solvent employed to dissolve the samples (Methanol/water (80:20, v/v)). Standard reference antibiotics, gentamycin $(15 \mu \mathrm{g})$, chloramphenicol $(30 \mu \mathrm{g})$ and ofloxacin $(5 \mu \mathrm{g})$ were used as positive controls for the tested bacteria. After incubation for $18-24$ hours at $37^{\circ} \mathrm{C}$ the diameters of the zone of inhibition (without diameter of the disc) were measured and expressed in $\mathrm{mm}$. The presence of a zone of inhibition indicates the activity of tested extracts against bacteria.

Minimum inhibitory concentrations (MICs) were also investigated for the bacterial strains which were determined as sensitive to the compounds in the disc diffusion assay; the minimum inhibitory concentration (MIC) for each extract tested was determined using the agar dilution technique (Tunçel and Nergiz, 1993). Appropriate amounts of each extract were aseptically added to the super-cooled sterile Mueller-Hinton to give final concentrations of $0.3,0.4,0.5,0.6,0.7,0.8,0.9,1,1.2,1.4,1.6,1.8$ and

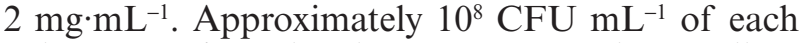
culture were inoculated as a spot onto the MuellerHinton containing the desired extract using a $1 \mu \mathrm{L}$ calibrated loop and the plates were incubated at $37{ }^{\circ} \mathrm{C}$ for $48 \mathrm{~h}$. The minimum concentration without bacterial growth was determined to be the MIC.

\subsection{Statistical analysis}

The data reported were subjected to analysis of variance using the Statistica 5.5 package (StatSoft 97 edition). Where statistical differences were noted, differences among packages were determined using the ANOVA/MANOVA following the NewmanKeuls test. Significance was defined at $p<0.05$.

\section{RESULTS AND DISCUSSION}

\subsection{Quality Indexes}

For the majority of the oils analyzed, the mean values of the quality parameter (acidity, peroxide index, and specific ultraviolet absorbance) fell within the ranges allowed by the IOC norms (2003) for the extra-virgin olive oil category (free acidity $\leq 0.8 \%$, peroxide value $\leq 20 \mathrm{meq} \cdot \mathrm{kg}-{ }^{1}, \mathrm{~K}_{270} \leq 0.22$ and $\left.\mathrm{K}_{232} \leq 2.50\right)$.

The peroxide value and acidity of the studied oil were in the ranges of $3.25-8.75 \mathrm{meq} \cdot \mathrm{kg}-{ }^{1}$ and $0.05-$ 0.23 ( $\%$ oleic acid), respectively. $\mathrm{K}_{270}$ was between 0.107 and 0.206 and $\mathrm{K}_{232}$ was in the range of 1.155 to 2.461 .

\subsection{Total phenols and $\boldsymbol{O}$-diphenols}

As shown in Table 1, the amount of total phenols and $O$-diphenols in the analyzed oils varies significantly $(p \leq 0.05)$ among the different cultivars. The results show that the amounts of total phenols and $O$-diphenols are highly variety-dependent. The average folin-ciocalteun content of total phenols in the samples analyzed was $218.66 \mathrm{mg} \cdot \mathrm{kg}^{-1}$, although a wide range of concentrations was observed, from $115 \mathrm{mg} / \mathrm{kg}$ (Chemlal Tazmalt variety) up to $420.95 \mathrm{mg} \cdot \mathrm{kg}^{-1}$ (Neb Djemel variety). The extract from the Neb Djemel variety had the highest contents of phenols and $O$-diphenols (420.95 and $29.67 \mathrm{mg} \cdot \mathrm{kg}^{-1}$, respectively), whereas, the extracts from the Chemlal Tazmalt variety (115.73 and 7.54 $\mathrm{mg} \cdot \mathrm{kg}^{-1}$, respectively) and Limli variety (123.43 and $5.68 \mathrm{mg} \cdot \mathrm{kg}^{-1}$, respectively) had the lowest (Table 1). Our results are higher than those found by Taniglan et al. (2007) for several Turkish olive oil varieties. A significant positive correlation between total phenol and $O$-diphenol contents was observed $(\mathrm{r}=0.88$, $\mathrm{p}<0.05)$. These results are in accordance with the correlation coefficient reported by Cerretani et al. (2006).

\subsection{HPLC profiles of phenols}

According to the classification of Montedoro et al. (1992), the total phenol contents determined by HPLC (Table 2) can be classified as high for $\mathrm{Neb}$ Djemel, Blanquette de Guelma and Bouricha, midrange for Akerma, Chemlal, Chemlal de Tazmalt, Ferkani, Limli and Tabelout and low for Aghenfas and Bouchouk Soummam.

The identified phenolic compounds are mainly secoiridoid derivatives, phenolic alcohols, flavonoids, and lignans. The main simple phenols found in the analyzed olive oils were hydroxytyrosol and tyrosol. The concentration of tyrosol varied from 2 to $28 \mathrm{mg} \cdot \mathrm{kg}^{-1}$ in all analyzed samples, which was higher than that of hydroxytyrosol $\left(0.5-5 \mathrm{mg} \cdot \mathrm{kg}^{-1}\right)$. These results agree with previous data found in

TABLE 1. Total phenols and O-diphenols (mean \pm SD, $n=3$ ) in different Algerian varieties of virgin olive oil

\begin{tabular}{lcc}
\hline Varieties & $\begin{array}{c}\text { Total phenols } \\
(\mathbf{m g} \cdot \mathbf{k g}-\mathbf{1})\end{array}$ & $\begin{array}{c}\text { O-diphenols } \\
(\mathbf{m g} \cdot \mathbf{k g}-\mathbf{1})\end{array}$ \\
\hline Aghenfas & $161.78 \pm 6.25^{\mathrm{c}}$ & $13.15 \pm 0.00^{\mathrm{d}}$ \\
Akerma & $130.93 \pm 7.68^{\mathrm{b}}$ & $10.07 \pm 0.00^{\mathrm{c}}$ \\
Blanquette de Guelma & $365.25 \pm 8.41^{\mathrm{f}}$ & $23.37 \pm 0.59^{\mathrm{g}}$ \\
Bouchouk Soummam & $152.17 \pm 7.24^{\mathrm{c}}$ & $10.92 \pm 0.00^{\mathrm{c}}$ \\
Bouricha & $369.79 \pm 6.88^{\mathrm{f}}$ & $15.65 \pm 0.86^{\mathrm{e}}$ \\
Chemlal & $234.38 \pm 6.43^{\mathrm{d}}$ & $15.49 \pm 0.18^{\mathrm{e}}$ \\
Chemlal Tazmalt & $115.73 \pm 4.36^{\mathrm{a}}$ & $7.54 \pm 0.00^{\mathrm{b}}$ \\
Ferkani & $243.23 \pm 2.87^{\mathrm{e}}$ & $19.30 \pm 0.00^{\mathrm{f}}$ \\
Limli & $123.43 \pm 0.79^{\mathrm{ab}}$ & $5.68 \pm 0.00^{\mathrm{a}}$ \\
Neb Djemel & $420.95 \pm 2.03^{\mathrm{g}}$ & $29.67 \pm 0.73^{\mathrm{h}}$ \\
Tabelout & $239.79 \pm 1.69^{\mathrm{e}}$ & $19.36 \pm 0.97^{\mathrm{f}}$ \\
\hline
\end{tabular}

${ }^{\mathrm{a}-\mathrm{h}}$ Means the column followed by different letters are significantly different $(P<0.05)$. 
Tunisian varieties (Haddada et al., 2008) and Spanish and Greek varieties grown in northern Tunisia (Allalout et al., 2009). Tyrosol was the main phenolic component present in the Blanquette de Guelma variety, with $28 \mathrm{mg} \cdot \mathrm{kg}^{-1}$ (Table 2).

The most abundant secoiridoids of the olive oil analyzed were secoiridoid derivatives of oleuropein and ligstroside; these results agree with previous data found for Spanish varieties (Brenes et al., 2000; Oliveras-Lopez et al., 2007). The content of oleuropein and ligstroside derivatives ranged from 50 to $26 \mathrm{mg} \cdot \mathrm{kg}^{-1}$ in Aghenfas oils to 276 and $173 \mathrm{mg} \cdot \mathrm{kg}^{-1}$ in Neb Djemel oils, respectively.

The amount of derivatives of oleuropein in all the analyzed samples was higher than that of the derivatives of ligstroside except for the Akerma, Limli and Tabelout varieties which showed higher contents of the derivatives of ligstroside (44, 62 and $124 \mathrm{mg} \cdot \mathrm{kg}^{-1}$, respectively). Arslan, (2012) noted that oleuropein was the most abundant phenolic in the olive oil of Turkish varieties.

Flavonoids are present in considerable amounts with concentrations varying from $10 \mathrm{mg} \cdot \mathrm{kg}^{-1}$ for the Limli variety to $44 \mathrm{mg} \cdot \mathrm{kg}^{-1}$ for the Aghenfas variety. These results were higher than those reported by Ilyasoglu et al. (2010). The main flavonoid compounds quantified in our study were luteolin and apigenin. Considerable quantitative differences in their concentrations among the different varieties were noted. The luteolin amount ranged from $6 \mathrm{mg} \cdot \mathrm{kg}^{-1}$ for the Tabelout variety to $38 \mathrm{mg} \cdot \mathrm{kg}^{-1}$ for the Akerma variety. Apigenin was present at a high level in the Chemlal Tazmalt variety $\left(14 \mathrm{mg} \cdot \mathrm{kg}^{-1}\right)$ compared to the others.
Lignans were also present in significant amounts in all the analyzed samples at concentrations ranging from $12 \mathrm{mg} \cdot \mathrm{kg}^{-1}$ in the Bouchouk Soummam variety to $51 \mathrm{mg} \mathrm{kg}^{-1}$ in the Bouricha variety. Although the variety Neb Djemel showed a high level of total polyphenols $\left(537 \mathrm{mg} \mathrm{kg}^{-1}\right)$, it contains only $21 \mathrm{mg} \cdot \mathrm{kg}^{-1}$ of lignans, on the other hand, the Chemlal Tazmalt variety, which is less rich in total polyphenols $\left(257 \mathrm{mg} \cdot \mathrm{kg}^{-1}\right)$ showed a high content of lignans $\left(41 \mathrm{mg} \cdot \mathrm{kg}^{-1}\right)$.

Lignans are the main component of the phenolic fraction of the olive seed and are practically absent in the pulp, leaves, and limbs, therefore their presence in the oil must be due to the breaking of the stones when the olives are crushed (Owen et al., 2000).

The presence of elenolic acid in olive oil in its free form is due to the hydrolysis of oleuropein, ligstroside, and related glucosidic compounds. The Neb Djemel variety was distinguished by a high concentration of elenolic acid $\left(68.4 \mathrm{mg} \mathrm{kg}^{-1}\right)$, the lowest value was noted for the Blanquette de Guelma variety $\left(13.3 \mathrm{mg} \cdot \mathrm{kg}^{-1}\right)$. This compound was found at a low concentration compared to the varieties cultivated in Chile and Spain (García-González et al., 2010) which did exceed $115 \mathrm{mg} \cdot \mathrm{kg}^{-1}$.

Recently, an interest in the oxidized form of virgin olive oil phenols has significantly increased, especially in relation to determination of freshness/ ageing status (Rovellini and Cortesi, 2002). The ratio between oxidized and natural forms is the key for a good quality judgment (Rovellini, 2008). A high amount of oxidized phenols was noted in the Chemlal Tazmalt variety $\left(67 \mathrm{mg} \cdot \mathrm{kg}^{-1}\right)$.

TABLE 2. Phenolic compounds composition obtained from Algerian virgin olive oil $\left(\mathrm{mg} \cdot \mathrm{kg}^{-1}\right)$, by HPLC analysis

\begin{tabular}{|c|c|c|c|c|c|c|c|c|c|c|c|}
\hline & Aghenfas & Akerma & $\begin{array}{l}\text { Blanquette } \\
\text { de Guelma }\end{array}$ & $\begin{array}{l}\text { Bouchouk } \\
\text { Soummam }\end{array}$ & Bouricha & Chemlal & $\begin{array}{l}\text { Chemlal } \\
\text { Tazmalt }\end{array}$ & Ferkani & Limli & $\begin{array}{c}\text { Neb } \\
\text { Djemel }\end{array}$ & Tabelout \\
\hline $\begin{array}{l}\text { Oleuropein } \\
\text { derivatives }\end{array}$ & 50 & 36 & 203 & 82 & 235 & 133 & 61 & 119 & 60 & 276 & 120 \\
\hline $\begin{array}{l}\text { Ligstroside } \\
\text { derivatives }\end{array}$ & 26 & 44 & 115 & 32 & 150 & 101 & 50 & 91 & 62 & 173 & 124 \\
\hline Hydroxytyrosol & 0.5 & 0.9 & 5 & 2 & 5 & 3 & 2 & 1 & 3 & 4 & 4 \\
\hline Tyrosol & 3 & 4 & 28 & 2 & 26 & 3 & 3 & 4 & 26 & 5 & 11 \\
\hline Total Flavonoids & 44 & 49 & 18 & 41 & 25 & 23 & 34 & 14 & 10 & 33 & 13 \\
\hline Apigenin & 12 & 11 & 6 & 12 & 7 & 8 & 14 & 4 & 3 & 13 & 7 \\
\hline Luteolin & 32 & 38 & 12 & 29 & 18 & 15 & 20 & 10 & 7 & 20 & 6 \\
\hline Lignans & 16 & 38 & 33 & 12 & 51 & 38 & 41 & 42 & 25 & 21 & 29 \\
\hline $\begin{array}{l}\text { Natural Elenolic } \\
\text { acid }\end{array}$ & 33.6 & 27.2 & 13.3 & 23.2 & 58.3 & 24.2 & 29.9 & 42.9 & 34.7 & 68.4 & 27.7 \\
\hline $\begin{array}{l}\text { Oxidized elenolic } \\
\text { acid }\end{array}$ & 0.20 & 0.12 & 0.11 & 0.02 & 0.09 & 0.05 & 00 & 0.02 & 0.07 & 0.02 & 0.20 \\
\hline Phenols oxidized & 14 & 15 & 51 & 18 & 55 & 54 & 67 & 13 & 42 & 19 & 22 \\
\hline $\begin{array}{l}\text { Total phenols } \\
\text { (HPLC) }\end{array}$ & 169 & 207 & 430 & 197 & 522 & 354 & 257 & 287 & 208 & 537 & 316 \\
\hline
\end{tabular}


The concentration of oxidized elenolic was very low in all varieties and was completely absent in the Chemlal Tazmalt variety, the highest values were noted for the Aghenfas, Tabelout varieties.

\subsection{Antioxidant activity}

\subsubsection{DPPH assay}

The results of DPPH radical-scavenging activities (Table 3 ) showed significant differences $(\mathrm{p}<0.05)$ among the varieties. The Blanquette de Guelma variety exhibited the best DPPH scavenging activity $(72.20 \%)$. The extracts of Limli, Akerma and Chemlal Tazmalt oils recorded the lowest percentages $(39.96,38.20$ and $36.57 \%$ respectively). These values were similar to those reported by Nakbi et al. (2010) for Tunisian cultivars (78.56 and 37.23\% for Chetoui and Chemlali varieties, respectively).

A significant correlation $(\mathrm{p}<0.05)$ is noted between DPPH radical-scavenging activity and phenolic compound content $(\mathrm{r}=0.72, \mathrm{p}<0.05)$ and $O$-diphenols $(\mathrm{r}=0.67, \mathrm{p}<0.05)$. These coefficients are in agreement with the report by SamaniegoSánchez et al. (2007) with the coefficient $r=0.79$ $(p<0.05)$ between total polyphenol and DPPH radical-scavenging activity.

The different radical-scavenging activities of our extracts might depend on the composition and profile of phenolic compounds among the varieties, particularly $O$-diphenols. The oleuropein derivatives were the main compounds found in eight varieties. Their antioxidant properties can be related to hydrogen donation and their ability to improve radical stability by forming an intra-molecular hydrogen bond between the free hydrogen of their phenoxyl radicals. The presence of a second hydroxyl group at the ortho-position significantly enhances their ability to act as an antioxidant as measured by the DPPH radical test.

On the other hand, the minor compounds present in the extracts such as flavonoids can control this activity, in fact, Bouchouk Soummam and Aghenfas have higher activity $(61.77$ and $60.15 \%)$ than the Ferkani (57.84\%) and Tabelout (49.34\%) varieties, despite their high total phenolic contents. This higher activity could be explained by the concentrations of flavonoids, in fact, Bouchouk Soummam and Aghenfas varieties presented higher flavonoid contents and contain 41 and $44 \mathrm{mg} \cdot \mathrm{kg}^{-1}$, respectively, corresponding to 26.03 and $23.71 \%$ of the total polyphenols, while the Ferkani and Tabelout varieties contain 13 and $14 \mathrm{mg} \cdot \mathrm{kg}^{-1}$, respectively, corresponding to 4.87 and $4.11 \%$ of the total polyphenols. The abilities of the flavonoids to scavenge the radicals were related the presence of functional groups in their structure, mainly the B-ring catechol, the 2,3-double bond conjugated with the 4-oxo function. Luteolin represents 72.7 and $70.7 \%$ of total flavonoids in extracts from Aghenfas and Bouchouk Soummam, respectively; this compound with two hydroxyl in the B-ring is several times stronger than apigenin (Majewska et al., 2011).

\subsubsection{ABTS. $^{+}$assay}

All the samples tested were able to scavenge the $\mathrm{ABTS}^{+}{ }^{+}$radical cation. Table 3 shows that the results were statistically different among the olive oil varieties $(\mathrm{p}<0.05)$. The results are also expressed as $\mathrm{IC}_{50}$, (Table 3), representing the concentration needed to decrease the initial $\mathrm{ABTS}^{+}$concentration by $50 \%$, a smaller $\mathrm{IC}_{50}$ value corresponds to a higher antioxidant activity of the extracted olive oil.

The best $\mathrm{ABTS}^{+}$scavenging activity was shown by the extract from the Bouricha variety $(73.38 \%)$ followed by the Blanquette de Guelma variety $(66.73 \%)$. They exhibited the lowest $\mathrm{IC}_{50}$ values $\left(0.12 \mathrm{mg} \cdot \mathrm{mL}^{-1}\right.$ and $0.18 \mathrm{mg} \cdot \mathrm{mL}^{-1}$ respectively), corresponding to a higher efficiency of the oil extracts to neutralize the radical $\mathrm{ABTS}^{+}$; whereas extracts from the Limli, Akerma and Chemlal Tazmalt varieties showed a lower $\mathrm{ABTS}^{+}$scavenging activity $(46.25,46.19$ and $45.25 \%)$ and higher $\mathrm{IC}_{50}$ values $(0.33,0.42$, $\left.0.37 \mathrm{mg} \cdot \mathrm{kg}^{-1}\right)$. A significant correlation between the polyphenol contents and the $\mathrm{ABTS}^{+}$scavenging ability $(r=0.72, p<0.05)$ was found. This coefficient is very close to that noted by Minioti and Georgiou (2010). Despite its high content of phenolic compounds, the Neb Djemel variety presented a lower antioxidant activity of $61.20 \%\left(\mathrm{IC}_{50}=0.25 \mathrm{mg} \cdot \mathrm{mL}^{-1}\right)$ compared with other varieties such as Bouricha and

TABLE 3. Scavenging activity of different extracts Algerian olive oils determined by DPPH and ABTS. ${ }^{+}$methods

\begin{tabular}{lccl}
\hline & \multicolumn{3}{c}{ Scavenging activity } \\
\cline { 2 - 4 } Varieties & DPPH (\%) & ABTS. $^{+}(\%)$ & $\begin{array}{c}\text { ABTS. }{ }^{+} \\
\left.\text {IC50 }^{+} \mathbf{m g ~ m L}-\mathbf{1}\right)\end{array}$ \\
\hline Aghenfas & $60.17 \pm 2.77^{\mathrm{cd}}$ & $58.33 \pm 1.61^{\mathrm{c}}$ & $0.280 \pm 0.010^{\mathrm{e}}$ \\
Akerma & $38.20 \pm 1.01^{\mathrm{a}}$ & $46.19 \pm 0.64^{\mathrm{a}}$ & $0.420 \pm 0.010^{\mathrm{g}}$ \\
Blanquette de & & & \\
Guelma & $72.20 \pm 2.19^{\mathrm{e}}$ & $66.73 \pm 1.54^{\mathrm{d}}$ & $0.180 \pm 0.010^{\mathrm{b}}$ \\
Bouchouk & & & \\
Soummam & $61.77 \pm 0.92^{\mathrm{de}}$ & $59.96 \pm 1.03^{\mathrm{c}}$ & $0.270 \pm 0.007^{\mathrm{d}}$ \\
Bouricha & $64.61 \pm 2.27^{\mathrm{d}}$ & $73.38 \pm 0.16^{\mathrm{e}}$ & $0.12 \pm 0.017^{\mathrm{a}}$ \\
Chemlal & $62.53 \pm 0.42^{\mathrm{de}}$ & $60.23 \pm 0.22^{\mathrm{c}}$ & $0.260 \pm 0.006^{\mathrm{cd}}$ \\
Chemlal & & & \\
Tazmalt & $36.57 \pm 1.71^{\mathrm{a}}$ & $45.25 \pm 1.66^{\mathrm{a}}$ & $0.370 \pm 0.011^{\mathrm{f}}$ \\
Ferkani & $57.84 \pm 1.23^{\mathrm{c}}$ & $57.64 \pm 0.03^{\mathrm{c}}$ & $0.300 \pm 0.005^{\mathrm{f}}$ \\
Limli & $39.96 \pm 1.79^{\mathrm{a}}$ & $46.25 \pm 1.05^{\mathrm{a}}$ & $0.330 \pm 0.005^{\mathrm{e}}$ \\
Neb Djemel & $63.37 \pm 0.45^{\mathrm{de}}$ & $61.21 \pm 1.64^{\mathrm{c}}$ & $0.250 \pm 0.002^{\mathrm{c}}$ \\
Tabelout & $49.34 \pm 1.71^{\mathrm{b}}$ & $49.82 \pm 1.48^{\mathrm{b}}$ & $0.320 \pm 0.005^{\mathrm{e}}$ \\
\hline
\end{tabular}

${ }^{\text {a-f }}$ Means the column followed by different letters are significantly different $(P<0.05)$. (mean $\pm \mathrm{SD}, \mathrm{n}=3)$. 
Olive oils from Algeria: Phenolic compounds, antioxidant and antibacterial activities $\bullet 7$

TABLE 4. Antibacterial activity (Inhibition zone diameter $(\mathrm{mm})$ ) of Algerian olive oil extracts against each bacterial species.

\begin{tabular}{|c|c|c|c|c|c|c|c|}
\hline \multirow[b]{2}{*}{ Varieties } & \multirow{2}{*}{$\begin{array}{c}\text { Concentrations } \\
\left(\mathrm{mg}^{\circ} \cdot \text { disc }^{-1}\right)\end{array}$} & \multicolumn{6}{|c|}{ Micro-organism Inhibition zone diameter (mm) } \\
\hline & & S. aureus & B. subtilis & L. innocua & E. coli & P. aeruginosa & K. pneumoniae \\
\hline \multirow[t]{4}{*}{ Aghenfas } & 1 & $19.00 \pm 0.00^{\mathrm{p}}$ & $4.00 \pm 1.00^{\mathrm{d}}$ & - & - & - & - \\
\hline & 0.5 & $17.66 \pm 0.57^{\text {no }}$ & $2.66 \pm 0.57^{\mathrm{c}}$ & - & - & - & - \\
\hline & 0.25 & $15.00 \pm 0.00^{\mathrm{kl}}$ & - & - & - & - & - \\
\hline & 0.12 & $13.00 \pm 0.00^{\mathrm{hij}}$ & - & - & - & - & - \\
\hline \multirow[t]{4}{*}{ Akerma } & 1 & $18.00 \pm 0.00^{\text {nop }}$ & $03.00 \pm 0.00^{\mathrm{cd}}$ & - & - & - & - \\
\hline & 0.5 & $17.33 \pm 1.15^{\mathrm{mn}}$ & $01.00 \pm 0.00^{\mathrm{ab}}$ & - & - & - & - \\
\hline & 0.25 & $14.33 \pm 1.15^{\mathrm{gk}}$ & - & - & - & - & - \\
\hline & 0.12 & $11.00 \pm 1,00^{\mathrm{fg}}$ & - & - & - & - & - \\
\hline Blanquette & 1 & $21.33 \pm 0.579$ & $06.33 \pm 0.57^{\mathrm{ij}}$ & $2.33 \pm 0.57^{\mathrm{a}}$ & $02.00 \pm 1.00^{\mathrm{ab}}$ & - & $04.00 \pm 1.00^{\mathrm{b}}$ \\
\hline \multirow[t]{3}{*}{ de Guelma } & 0.5 & $17.33 \pm 0.57^{\mathrm{mn}}$ & $05.33 \pm 0.57^{\mathrm{fg}}$ & - & $00.66 \pm 0.57^{\mathrm{a}}$ & - & $03.33 \pm 0.57^{b}$ \\
\hline & 0.25 & $13.00 \pm 0.00^{\mathrm{hij}}$ & $04.00 \pm 0.00^{\mathrm{de}}$ & - & - & - & $02.66 \pm 0.57^{b}$ \\
\hline & 0.12 & $08.33 \pm 0.57^{\mathrm{de}}$ & $01.00 \pm 0.00^{\mathrm{a}}$ & - & - & - & $00.66 \pm 0.57^{\mathrm{a}}$ \\
\hline Bouchouk & 1 & $10.33 \pm 0.57^{\mathrm{f}}$ & $04.00 \pm 0.00^{\mathrm{de}}$ & - & - & - & - \\
\hline \multirow[t]{3}{*}{ Soummam } & 0.5 & $08.33 \pm 0.57^{\mathrm{d}}$ & $02.33 \pm 0.57^{\mathrm{bc}}$ & - & - & - & - \\
\hline & 0.25 & $05.00 \pm 0.00^{\mathrm{c}}$ & $01.00 \pm 0.00^{\mathrm{ab}}$ & - & - & - & - \\
\hline & 0.12 & $02.00 \pm 0.00^{\mathrm{ab}}$ & - & - & - & - & - \\
\hline \multirow[t]{4}{*}{ Bouricha } & 1 & $26.00 \pm 0,00^{\mathrm{s}}$ & $11.00 \pm 0.81^{1}$ & $09.66 \pm 0.47^{c}$ & $08.66 \pm 0.94^{\mathrm{d}}$ & $09.00 \pm 0.00^{\mathrm{d}}$ & $10.66 \pm 0.47^{\mathrm{e}}$ \\
\hline & 0.5 & $22.66 \pm 0.47^{\mathrm{r}}$ & $10.33 \pm 0.94^{1}$ & $09.00 \pm 0.81^{\mathrm{bc}}$ & $07.66 \pm 0.94^{\mathrm{d}}$ & $07.66 \pm 0.47^{c}$ & $08.00 \pm 0.81^{\mathrm{d}}$ \\
\hline & 0.25 & $20.33 \pm 0.47^{q}$ & $09.33 \pm 0.47^{\mathrm{k}}$ & $08.00 \pm 0.81^{\mathrm{bc}}$ & $07.00 \pm 0,00^{\mathrm{c}}$ & $07.00 \pm 0.00^{\mathrm{b}}$ & $07.00 \pm 0.00^{\mathrm{cd}}$ \\
\hline & 0.12 & $17.00 \pm 0.00^{\mathrm{mn}}$ & $08.66 \pm 0.47^{\mathrm{jk}}$ & $07.33 \pm 0.47^{b}$ & $06.00 \pm 0.81^{\mathrm{b}}$ & $06.00 \pm 0.00^{\mathrm{a}}$ & $06.00 \pm 0.00^{\mathrm{c}}$ \\
\hline \multirow[t]{4}{*}{ Chemlal } & 1 & $16.00 \pm 0,00^{\mathrm{lm}}$ & $06.00 \pm 0.00^{\mathrm{gh}}$ & - & - & - & - \\
\hline & 0.5 & $12.00 \pm 1.00^{\mathrm{gh}}$ & $04.33 \pm 0.57^{\mathrm{e}}$ & - & - & - & - \\
\hline & 0.25 & $09.66 \pm 0,57^{\mathrm{f}}$ & $02.00 \pm 0.00^{\mathrm{abc}}$ & - & - & - & - \\
\hline & 0.12 & $07.33 \pm 0.57^{\mathrm{d}}$ & $01.00 \pm 0.00^{\mathrm{a}}$ & - & - & - & - \\
\hline Chemlal & 1 & $04.33 \pm 0.57^{\mathrm{c}}$ & - & - & - & - & - \\
\hline \multirow[t]{4}{*}{ Tazmalt } & 0.5 & $03.00 \pm 0.00^{\mathrm{b}}$ & - & - & - & - & - \\
\hline & 0.25 & $01.00 \pm 0.00^{\mathrm{a}}$ & - & - & - & - & - \\
\hline & 0.12 & - & - & - & - & - & - \\
\hline & 1 & $14.66 \pm 0.57^{\mathrm{k}}$ & $06.66 \pm 0.57^{\mathrm{h}}$ & - & - & - & - \\
\hline \multirow[t]{4}{*}{ Ferkani } & 0.5 & $09.66 \pm 0.57^{\mathrm{f}}$ & $04.66 \pm 0.57^{\mathrm{ef}}$ & - & - & - & - \\
\hline & 0.25 & $04.66 \pm 0.57^{\mathrm{c}}$ & $02.00 \pm 0.00^{\mathrm{ab}}$ & - & - & - & - \\
\hline & 0.12 & $02.66 \pm 0.57^{b}$ & $01.00 \pm 0.00^{\mathrm{a}}$ & - & -- & - & - \\
\hline & 1 & $12.66 \pm 0.57^{\mathrm{hi}}$ & $2.33 \pm 00.57^{\mathrm{bc}}$ & - & - & - & - \\
\hline \multirow[t]{4}{*}{ Limli } & 0.5 & $07.66 \pm 0.57^{\mathrm{d}}$ & $01.00 \pm 0.00^{\mathrm{ab}}$ & - & - & - & - \\
\hline & 0.25 & $05.66 \pm 0.57^{\mathrm{c}}$ & - & - & - & - & - \\
\hline & 0.12 & $02.66 \pm 0.57^{b}$ & - & - & - & - & - \\
\hline & 1 & $19.00 \pm 0.00^{\mathrm{p}}$ & $08.66 \pm 0.57^{\mathrm{i}}$ & - & - & - & - \\
\hline \multirow[t]{4}{*}{ Neb Djemel } & 0.5 & $17.33 \pm 0.57^{\mathrm{mn}}$ & $06.66 \pm 0.57^{\mathrm{h}}$ & - & - & - & - \\
\hline & 0.25 & $14.00 \pm 1.00^{\mathrm{ijk}}$ & $04.00 \pm 0.00^{\mathrm{de}}$ & - & - & - & - \\
\hline & 0.12 & $10.00 \pm 1.00^{\mathrm{f}}$ & $02.00 \pm 0.00^{\mathrm{abc}}$ & - & - & - & - \\
\hline & 1 & $05.00 \pm 0.00^{\mathrm{c}}$ & - & - & - & - & - \\
\hline \multirow[t]{3}{*}{ Tabelout } & 0.5 & $03.00 \pm 1.00^{\mathrm{b}}$ & - & - & - & - & - \\
\hline & 0.25 & $01.66 \pm 0.57^{\mathrm{ab}}$ & - & - & - & - & - \\
\hline & 0.12 & - & - & - & - & - & - \\
\hline
\end{tabular}

Means (mean $\pm \mathrm{DS}, \mathrm{n}=3$ ) with the same letter in the same column are not significantly different. Diameter of zone of inhibition (mm) not including diameter of $6 \mathrm{~mm}$ disc;. - : No inhibitory effects. 
Blanquette de Guelma. This could be explained by a higher content of free hydroxtyrosol and lignans of these two varieties. Literature data attests that hydroxytyrosol shows a high antioxidant activity (Lavelli, 2002). Regarding lignans' antioxidant power, Owen et al. (2000) showed the existence of a clear correlation between the radical scavenging ability of a virgin olive oil phenolic extract and the lignan concentration. The antioxidant activity of $(+)$-pinoresinol was more prominent that the activity of the following compounds: ligstroside aglycon, tyrosol, elenolic acid (Carrasco-Pancorbo et al., 2005).

\subsection{Antibacterial Activity}

The different olive oils extracts at different concentrations $\left(0.12,0.25,0.5\right.$ and $\left.1 \mathrm{mg} \cdot \mathrm{disc}^{-1}\right)$ were screened for their antimicrobial activity against $B$. subtilis, S. aureus and L. innocua (Gram-positive), E. coli, $P$. aeruginosa, and $K$. pneumoniae (Gramnegative) following the agar diffusion method (Table 4). The minimal inhibitory concentration (MIC) values for bacteria (Table 5) were determined. Standard antibiotics (Gentamycin, Chloramphenicol and Ofloxacine) were used, and are also mentioned in Table 6. The solvents used for extraction were also used for dissolving the extracts, and all the solvent controls did not show any activity (data not shown).

As shown in Table 4, the results of the in-vitro antimicrobial activity assay showed that the phenolic extracts from the Bouricha and Blanquette de Guelma varieties possessed broad antibacterial activity against the microorganisms tested. The zone of inhibition varied from 6 to $26 \mathrm{~mm}$ and from 0.6 to $21 \mathrm{~mm}$, respectively. The extracts from the Chemlal Tazmalt and Tabelout varieties only showed activity against $S$. aureus. Whereas the others eight extracts displayed a moderate activity against $S$. aureus and B. subtilis. Our results are in concordance with those reported by Medina et al. (2006) who observed higher activity in virgin olive oils and none in other edible vegetable oils (corn, sunflower, soybean, rapeseed and cotton). The authors attributed this activity of olive oil to the phenolic compounds; the dialdehidic form of decarboxymethyl oleuropein and ligstroside aglycons, hydroxytyrosol, and tyrosol were the phenolic compounds that statistically correlated with bacterial survival. A recent study by Karaosmanoglu et al. (2010) showed different antimicrobial activities among extra virgin olive oil, refined olive oil and canola oil against three microorganisms (E. coli, S. enteritidis and L. monocytogenes).This activity was also related to the high concentrations of phenolic compounds found in virgin olive oils. The oil contained many phenolic compounds; an increase in their overall effect can be related to a synergistic interaction.

The effect of each individual phenolic compound, isolated by HPLC, against $L$. monocytogenes, showed that the dialdehydic form of decarboxy methyligstroside presented a potent antimicrobial activity. These results are in agreement with ours because the Algerian olive oil varieties presented high percentages of oleuropein and ligtroside derivatives.

Gentamycine, chloramphenicol and ofloxacine, which were used as a positive control, had inhibition zones ranging from 28 to $38 \mathrm{~mm}$. S. aureus, with high sensitivity to some extracts, was also sensitive to antibiotics at a concentration much lower than methanolic extracts.

The MICs reported in Table 6 show quantitative evidence of the antimicrobial activity of different extracts the olive oil varieties. The MICs of the extracts varied from 0.6 to $2 \mathrm{mg} \cdot \mathrm{mL}^{-1}$ on most of the tested bacteria. In fact, the growth of S.aureus was significantly inhibited $\left(0.6-1.6 \mathrm{mg} \cdot \mathrm{mL}^{-1}\right)$. The lowest MIC value $\left(0.6 \mathrm{mg} \cdot \mathrm{mL}^{-1}\right)$ was observed for the extract from Bouricha on S.aureus. These values of MIC are higher than those reported by Pereira et al. (2006) for the phenolic compound extract from Portuguese table olives. Nevertheless, they are in accordance with the results reported by Tuncel and Nergis (1993) on the MIC of ferulic, vanillic, and caffeic acids and tyrosol against $\mathrm{S}$. aureus, which were determined as $0.6,0.55,0.4$ and $0.6 \mathrm{mg} \cdot \mathrm{mL}^{-1}$, respectively, by the agar dilution method.

The MICs of phenolic compounds that inhibit bacterial growth are much higher than those found in olive oils. In the study by Bisignano et al. (1999), minimum inhibitory concentrations of hydroxytyrosol against Staphylococcus aureus (penicillin susceptible) and Staphylococcus aureus (penicillinresistant) were determined; they ranged from 3.9$31.25 \mu \mathrm{g} \cdot \mathrm{mL}^{-1}$ and 3.9-31.25 $\mu \mathrm{g} . \mathrm{mL}^{-1}$, respectively. These concentrations of this phenolic compound

TABLE 5. Antibacterial activity (Inhibition zone diameter) of antibiotics against each bacterial species.

\begin{tabular}{lccccccc}
\hline & \multirow{2}{*}{$\begin{array}{c}\text { Concentrations } \\
\left(\boldsymbol{\mu g} \cdot \mathbf{d i s c}^{-1}\right)\end{array}$} & S. aureus & B. subtilis & L. innocua & E. coli & P. aeruginosa & K. pneumoniae \\
\cline { 3 - 8 } & 15 & $30.7 \pm 1.2$ & $34.0 \pm 0.0$ & $26.7 \pm 1.2$ & $28.7 \pm 1.2$ & $26.0 \pm 0.0$ & - \\
Gentamycin & 30 & $30.7 \pm 1.2$ & $34.7 \pm 1.2$ & $31.3 \pm 1.2$ & $34.7 \pm 1.2$ & $22.7 \pm 1.2$ & - \\
Chloramphenicol & 5 & $32.0 \pm 0.0$ & $36.7 \pm 1.2$ & $38.0 \pm 0.0$ & - & $38.0 \pm 2.0$ & $30.0 \pm 0,0$ \\
Ofloxacin & 5 &
\end{tabular}

Diameter of zone of inhibition $(\mathrm{mm})$ including diameter of $6 \mathrm{~mm}$ disc; - : No inhibitory effects (mean $\pm \mathrm{SD}, \mathrm{n}=3$ ). 
TABLE 6. Minimum Inhibitory Concentration (MIC) of different extracts of Algerian olive oils against Each Bacterial Species

\begin{tabular}{lcccccc}
\hline & \multicolumn{7}{c}{ MIC } & \multicolumn{7}{c}{$\cdot \mathbf{m L}^{-\mathbf{1}}$} & & \\
\cline { 2 - 7 } & S. aureus & B. subtilis & L. innocua & P.aeruginosa & E. coli & K. pneumoniae \\
\hline Aghenfas & 0.9 & 1.3 & NT & NT & NT & NT \\
Akerma & 0.9 & 1.4 & NT & NT & NT & NT \\
Blanquette de Guelma & 0.7 & 1.2 & 1.8 & NT & 1.8 & $>2$ \\
Bouchouk Soummam & 1.2 & 2 & NT & NT & NT & NT \\
Bouricha & 0.6 & 1.2 & 1.6 & $1 / 1.1$ & 1.8 & $>2$ \\
Chemlal & 1.2 & 1.2 & NT & NT & NT & NT \\
Chemlal Tazmalt & 1.6 & NT & NT & NT & NT & NT \\
Ferkani & 1 & 1.2 & NT & NT & NT & NT \\
Limli & 1.2 & 1.8 & NT & NT & NT & NT \\
Neb Djemel & 0.9 & 1.2 & NT & NT & NT & NT \\
Tabelout & 1.6 & NT & NT & NT & NT & NT \\
\hline
\end{tabular}

$\mathrm{NT}=$ Not tested

are about 1000 times higher than the levels of those in extra virgin olive oil, EVOO.

Among the bacteria used in the present study, $S$. aureus (Gram-positive) showed a higher sensitivity to different extracts with the largest zone of inhibition and lowest MIC (Tables 4 and 6). This was consistent with the results from previous reports, which suggested a higher susceptibility of food-borne pathogenic Gram-positive bacteria to polyphenols compared with Gram-negative bacteria (Brenes et al., 2006). This observation can be attributed to differences in the structure of the bacteria cell wall. The less complex the structure of the cell wall is in the Gram-positive bacteria, the more permeable it is to anti-microbial compounds (Papadopoulou et al., 2005).

Although the anti-microbial effects of various phenolic extracts are well documented, the mechanisms of action of these products and their components are not fully understood. Polyphenols are thought to cause surface activity that damages the membranes of bacterial cells, to inhibit its enzymes, or to interfere with the production of certain amino acids necessary for bacterial growth (Cowan, 1999). Antibacterial activity of olive oil's phenolic compounds is due to the presence of the ortho-diphenolic system (catechol) (Bisignano et al., 1999). Therefore, the position and number of hydroxyl groups on the phenol group are thought to be related to their relative toxicity to microorganisms, with evidence that increasing hydroxylation results in an increase in anti-microbial activity. Oleuropein was significantly less toxic to bacterial cells than hydroxytyrosol; one can speculate that the glycosidic group of oleuropein might render the unable to penetrate cell membranes or to reach the target site.

\section{CONCLUSIONS}

The phenolic composition represents a useful contribution to the biochemical characterization of the Algerian olive oil cultivars. Derivatives of oleuropein and ligstroside, the abundant phenolic compounds hydroxytyrosol, tyrosol, flavonoids, and lignans vary quantitatively according to the variety; in fact, the cultivar affects quantitative phenolic factions of these EVOOS, demonstrating a unique and characteristic phenolic profile. These phenolic fractions also influenced and allowed to differentiate the total antioxidant and antibacterial activity observed in the cultivars.

The results obtained in the present work reveal that Algerian olive oils may constitute a good source of healthy compounds in the diet, especially phenolic compounds, suggesting that their consumption could be useful in the prevention of diseases in which free radicals are implicated and may be good candidates for applications such as antimicrobial agents against bacteria responsible for human gastro-intestinal and respiratory tract infections and foodborne pathogens, particularly important against $S$. aureus, a microorganism extensively studied due to its ability to produce enterotoxins. As far as we know, this is the first report considering the antioxidant and anti-microbial potential of phenolic compounds in EVOO from Algeria.

\section{REFERENCES}

Allalout A, Krichène D, Methenni K, Taamalli A, Oueslati I, Daoud D, Zarrouk M. 2009. Characterization of virgin olive oil from super intensive Spanish and Greek varieties grown in northern Tunisia. Sci. Hortic. 120, 77-83. 
Arslan D. 2012. Physico-chemical characteristics of olive fruits of Turkish varieties from the province of Hatay. Grasas Aceites 63,158-166

Bendini A, Bonoli M, Cerretani L, Bigguzi B, Lercker G, Toschi, TG. 2003. Liquid and solid-phase extractions of phenols from virgin olives oil and their separation by chromatographic and electrophoretic methods. J. Chromatogr. 985, 425-433.

Bisignano G, Tomaino A, Cascio RL, Crisafi G, Uccella N, Saija, A.1999. On the in-vitro antimicrobial activity of oleuropein and hydroxytyrosol. J. Pharm. Pharmacol. 51, 971-974.

Brenes M, Hidalgo, FJ, García A, Ríos JJ, García P, Zamora R, Garrido A. 2000. Pinoresinol and 1-acetoxypinoresinol, two new phenolic compounds identified in olive oil. $\mathrm{J} . \mathrm{Am}$. Oil Chem Soc. 77, 715-720.

Brenes M, Medina E, Romero C, De Castro A. 2006. Antimicrobial activity of olive oil. Agro Food Industry hi-tech, 18, 6-8.

Bubonja-Sonje M, Giacometti J, Abram M. 2011. Antioxidant and antilisterial activity of olive oil, cocoa and rosemary extract polyphenols. Food Chem. 127, 1821-1827.

Carrasco-Pancorbo A, Cerretani L, Bendini A, Segura Carretero A, Del Carlo M, Gallina-Toschi T, Lercker G, Compagnone D, Fernández-Gutiérrez A. 2005. Evaluation of the Antioxidant Capacity of Individual Phenolic Compounds in Virgin Olive Oil. J. Agri. Food Chem. 53, 8918-8925.

Cerretani L, Bendini A, Del Caro A, Piga A, Vacca V, Caboni M F. Toschi TG. 2006. Preliminary characterization of virgin olive oils obtained from different cultivars in Sardinia. Eur. Food Res. Technol. 222, 354-361

Cicerale S, Conlan X A, Sinclair AJ, Keast R S J. 2009. Chemistry and health of olive oil phenolics. Crit. Rev. Food Sci. Nutr. 49, 218-236.

Cicerale S, Lucas L, Keast, R. 2010. Biological activities of phenolic compounds present in virgin olive oil. Int. J. Mol. Sci. $11,458-479$.

Cowan MM. 1999. Plant products as antimicrobial agents. Clin Microbiol Rev. 12, 564-582.

Favati F, Caporale G, Bertuccioli, M. 1994. Rapid determination of phenol content in extra virgin olive oil. Grasas Aceites 45, 68-70.

Furneri PM, Piperno A, Saija A, Bisignano G. 2004. Antimicrobial activity of hydroxytyrosol. Antimicrob. Agents Ch. 48, 4892-4894.

Haddada FM, Krichène D, Manai H, Oueslati I, Daoud D, Zarrouk M. 2008. Analytical evaluation of six monovarietal virgin olive oils from Northern Tunisia. J. Lipid Sci Technol. 110, 905-913.

Ilyasoglu H, Ozcelik B, Hoed V V, Verhe R. 2010. Characterization of Aegean Olive Oils by Their Minor Compounds. J. Am. Oil Chem. Soc. 87, 627-636.

IOC 1996. Analyse spectrophotometrique dans l'ultraviolet. Conseil Oléicole International/T20/ Doc 196 juin 1996, Madrid. Espagne.

IOC 2003. Classification des huiles d'olive. Normes Internationales applicables à l'huile d'olive et l'huile de grignon d'olive. Conseil Oléicole International.

IUPAC 1979. International Union of Pure and Applied Chemistry. Méthodes d'analyses des matières grasses et dérivés. 6éme édition. Edition ETIG. Paris.

García-González D L, Romero N, Aparicio, R. 2010. Comparative Study of Virgin Olive Oil Quality from Single Varieties Cultivated in Chile and Spain. J. Agric. Food Chem. 58, 12899-12905.

Kappel VD, Costa GM, Scola G, Silva FA, Landell MF, Valente P, Souza D, Vanz D, Reginatto F, Moreira CDG. 2008. Phenolic content and antioxidant and antimicrobial properties of fruits of Capsicum baccatum L. var. pendulum at different maturity stages. J. Med. Food 11, 267-274.

Karaosmanoglu H, Soyer F, Ozen B, Tokatli F. 2010. Antimicrobial and Antioxidant Activities of Turkish Extra Virgin Olive Oils. J. Agric. Food Chem. 58, 8238-8245

Keceli T, Gordon MH. 2001. The antioxidant activity and stability of the phenolic fraction of green olives and extra virgin olive oil. J. Sci. Food Agric. 81, 1391-1396.
Lavelli L. 2002. Comparison of the antioxidant activities of extra virgin olive oils $J$. Agri. Food Chem 50, 7704-7708.

Majewska M, Skrzycki M, Podsiad M, Czeczot H. 2011. Evaluation of antioxidant potential of flavonoids: an in vitro study. Acta Pol. Pharm. 68, 611-5.

Medina E, De Castro A, Romero C, Brenes M. 2006. Comparison of the concentrations of phenolic compounds in olive oils and other plant oils: correlation with antimicrobial activity. J. Agric. Food Chem 54, 4954-4961.

Minioti KS, Georgiou CA. 2010. Comparison of different tests used in mapping the Greek virgin olive oil production for the determination of its total antioxidant capacity. Grasas Aceites 61, 45-51

Montedoro GF, Servili M, Baldioli M, Miniati E. 1992.Simple and hydrolyzable compounds in virgin olive oil. 1. Their extraction, separation and quantitative and semiquantitative evaluation by HPLC. J. Agric. Food Chem. 40, 1571-76.

Nakbi A, Issaoui M, Dabbou S, Koubaa N, Echbili A, Hammami M, Attia N. 2010. Evaluation of antioxidant activities of phenolic compounds from two extra virgin olive oils. J. Food Compos. Anal. 23, 711-715.

NGD C89. 2010. Determinazione dei biofenoli negli oli di oliva mediante HPLC. 1-8

Oliveras-Lopez M J, Innocenti M, Giaccherini C, Ieri F, Romani A, Mulinac N. 2007. Study of the phenolic composition of spanish and italian monocultivar extra virgin olive oils: Distribution of lignans, secoiridoidic, simple phenols and flavonoids. Talanta 73, 726-732.

Owen RW, Mier W, Giacosa A, Hull WE, Spiegelhalder B, Bartsch H. 2000. Identification of lignans as major components in the phenolic fraction of olive oil. Clin. Chem. 46, 976-988.

Papadopoulou C, Soulti K, Roussis IG 2005. Potential Antimicrobial Activity of Red and White Wine Phenolic Extracts against Strains of Staphylococcus aureus, Escherichia coli and Candida albicans. Food Technol. Biotechnol. 43, 41-46.

Pereira JA, Pereira APG, Ferreira IGFR, Valentap P, Andrade PB, Seabra R, Estivinho L, Bento A. 2006. Table olives from Portugal; phenolic compounds, antioxidant potential and antimicrobial activity. J. Agric. Food Chem. 54, 8425-8431.

Re R, Pellegrini N, Proteggente A, Pannala A, Yang M, RiceEvans C. 1999. Antioxidant activity applying an improved ABTS $^{+}$radical cation decolorization assay. Free Radic. Biol. Med. 26, 1231-1237.

Romero C, Medina E, Vargas J, Brenes M, De Castro A. 2007. In vitro activity of olive oil polyphenols against Helicobacter pylori. J. Agric. Food Chem. 55, 680-686.

Rovellini P, Cortesi N. 2002. Liquid chromatography-mass spectrometry in the study of oleuropein and ligstroside aglycons in virgin olive oils: aldehydic, dialdehydic forms and their oxidized products. Riv. Ital. Sost. Grasse 79, 1-14.

Rovellini P. 2008. Elenolic acid in virgin olive oil: liquid chromatography-mass spectrometry method. Riv. Ital. Sost. Grasse 85, 21-31.

Samaniego-Sánchez C, Troncoso González AM, García-Parrilla MC, Quesada Granados JJ, López García de la Serrana H, López Martínez MC. 2007. Different radical scavenging tests in virgin olive oil and their relation to the total phenol content Anal. Chim. Acta 593, 103-107.

Servili M, Esposto S, Fabiani R, Urbani S, Taticchi A, Mariucci F, Selvaggini R Montedoro G F. 2009. Phenolic compounds in olive oil: antioxidant, health and Organoleptic activities according to their chemical structure. Inflammopharmacol. $17,1-9$

Taniglan K, Ozcan M, Unver A, 2007. Physical and chemical characteristics of five Turkish olive (Olea europea L.) varieties and their oils. Grasas Aceites 58, 142-147

Tsimidou M, Papadopoulos G, Boskou D. 1992. Phenolic compounds 443 and stability of virgin olive oil-Part I. Food Chem. 45, 141-144.

Tunçel G, Nergiz C. 1993. Antimicrobial effect of some olive phenols in a laboratory medium. Lett. Appl Microbiol. 17, 300-302.

Visioli F, Galli C. 1998. Olive Oil Phenols and their Potential Effects on Human Health J. Agric. Food Chem. 46, 4292-4296. 